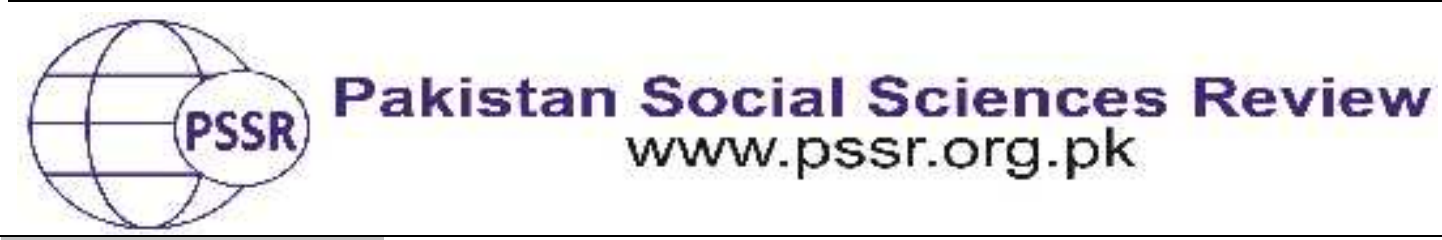

RESEARCH PAPER

\title{
Animation Based Learning and Traditional Method of Teaching in English Subject: A Comparative Study
}

\author{
Dr. Syeda Samina Tahira ${ }^{1}$ Hina Arshad ${ }^{2}$ Rubab Batool ${ }^{3}$
}

1. HoD, Department of Education, GC Women University Faisalabad, Punjab, Pakistan

2. Lecturer, Department of Education, G.C. Women University Faisalabad, Punjab, Pakistan

3. Lecturer, Department of Education, G.C. Women University Faisalabad, Punjab, Pakistan

\begin{tabular}{|c|c|}
\hline 118 & \\
\hline $\begin{array}{l}2021 \\
021 \\
021\end{array}$ & $\begin{array}{l}\text { The objectives of the study were to compare the effectiveness of } \\
\text { animation based learning and traditional method of teaching, to } \\
\text { investigate the effectiveness of high, mediocre and low } \\
\text { achievers of traditional method of teaching as compared to } \\
\text { high, mediocre and low achievers of animation-based learning }\end{array}$ \\
\hline $\begin{array}{l}\text { Keywords: } \\
\text { Animation } \\
\text { Based Learning, } \\
\text { Teaching of } \\
\text { English } \\
\text { Grammar. } \\
\text { Traditional } \\
\text { Method of } \\
\text { Teaching }\end{array}$ & $\begin{array}{l}\text { private sector Dar-e-Arqam School Model Town Campus Faisalabad. } \\
\text { As the study was experimental in nature therefore, all fourth } \\
\text { graders (44) consisted in two sections were selected, first section } \\
\text { for control group (22) was treated with traditional method of } \\
\text { teaching and second section for experimental group (22) was } \\
\text { treated with animation-based learning. The Pretest-Posttest } \\
\text { Equivalent-Groups Design was selected. Approximately, one } \\
\text { month lesson planning was used for both teaching }\end{array}$ \\
\hline spondin & $\begin{array}{l}\text { m the pre-test that was conducted at the beginning of the } \\
\text { Idy and from the post-test that was conducted after } \\
\text { atment. Statistically conclusions of the study went to the } \\
\text { or of animation-based learning and proved that animation- } \\
\text { sed learning is admirable way of teaching to be taught to } \\
\text { mprehensible the grammar concepts as well as to retain the } \\
\text { son. This kind of study may be conducted at public sector in } \\
\text { ure. }\end{array}$ \\
\hline
\end{tabular}

\section{Introduction}

Education is one of the most important activity in which human being engage. Education is the only way to change or improve society. This is the sum total of one's learning experiences during a lifetime-not just organized formal learning experience in schools, but all learning experience (Ahmad,2016). Additionally, it is 
the basic foundation upon that whole building of education and human development stands. Furthermore, it provides the strength to every child to cope up with all kinds of activities which is helpful for every walk of life (Sequeira, 2012).

Education system depends on various elements like curriculum, objectives, teaching, learning, environment and community etc. Teaching is a pleasant profession, the location it's far viewed to be one of the hard additives of the coaching process. In other words, Teachers are accountable of deciding on the proper method of coaching according to their scholars 'age, mental level, student's differences as well as student's interest, to get them engaged in an first-rate lesson (Birbaumer\& Schmidt,2010).

Today teacher-centered mode in English is to guide the students traditionally and focused on bookish memorization. The concepts of English are difficult to understand as well as to learn and retain specially grammar concepts. With the development of the society and economy, more and extra talents a success of getting to know English are badly wanted within the world. Consequently, normal English schooling mode is appreciably challenged at all levels (Liu \& Long, 2014).

One important combination of media is animation, that been define as an image in motion. Animation is a success features are improvements which can brighten up the gaining knowledge of enjoy. The power of gaining knowledge of through animation will enable a much wider variety of stimuli in accordance make bigger the student engagement in mastering (Dwyer \& Dwyer,2003).

Today's learning activities of students are totally different. Students have a variety of technology available to them at home. Entertainments such as television programs, computer, Internet activities, iPhones and iPods are quickly replacing the older and cheaper ways to entertainment such as reading story books and outdoor healthy and physically activities. Now, it is necessary to change the teaching methodology to fulfill the needs of modern age. A teacher has to replace older teaching techniques with newer teaching techniques. Teachers need to be able to adapt their curriculum and delivery of material to the needs of the students. By adapting teaching methods to the need's students, it is helped that students will be able to meet and exceed goals and expectation. It is necessary for education to change and adapt its curriculum in the order to arise students' understanding and improve standardized test achievements.

\section{Literature Review}

In recent years, a great bent towards the use of technology and its use into the set of different courses has gained the enormous importance. New a day, multimedia techniques in the classroom are becoming more and more popular. Modern technology is assessable for every student easily. Students are much attach into the multimedia. So, it is necessary for today's teacher to enhance their teaching in the light of modern technology. Animation, one small part of the computer 
revolution is very important part of high technology. The high-powered multimedia involves the learner in the learning by listening, seeing, reflecting, doing and participating(Islam, et al.,2014).Animation based learning capture the student's attention towards the learning span. Teaching of English grammar sometime board and make difficult to understand for the students. Animation provides an effective teaching tool. Many researchers have been performed beneficial research on the use of animation in instructing of English at unique level (Abdo \& Awabdeh,2017).

Islam, et al, (2014) claimed that child education is fruitful when learning through animation. Teachers always try to teach the students by textbooks through traditional ways. However, learning and teaching ways could be changed for the development of education in the light of communication technology (ICT). Now it is necessary to carry the students with interacted learning system so that they can improve their learning skills in an effected way. It is also needed to create high quality and realistic learning environment for the students. Visual learning way is effective teaching style to catch the student's interaction towards the conceptual understanding. An experimental study conducted at Dhaka Primary School. Teaching in this project divided into three sections; in first section teacher taught with traditional method on same material, in second section teacher taught by using visual learning on same material and in third section teacher taught with animated video on the same material with verbal instructions. The visual material with verbal instructions is the blended approach of learning. The results of third one section much better than the other two teaching method. In this section student's result and perception were very positive towards the blended technique. So, this study proved that blended learning system which concerned with animated videos and verbal instructions best appropriate method to teach the children at school level students.

Rosen (2009) investigated the results of an animation-based mastering surroundings on transfer the information and on motivation for the science and generation mastering. This takes a look at carried out on fifth and seventh grade students at Israel School. Students participated in this take a look at right now a week in technology and generation classes that incorporated the animation-based studying environment. This takes a look at carried on three months. At the give up of the treatment the effects confirmed significant impact of animation based totally online studying. Students perceived themselves as playing a greater principal function in study room interaction, confirmed high reaction and interest as well as centered greater using era and experiments during instructions.

Abdo \& Awabdeh (2017) conducted a study on Animated Videos Prove to be Beneficial in Teaching English Grammar as EFL: A Neurological Study of How Students Learn and Retain English Grammar. This examine investigated using animation movies of teaching English grammar wherein it taken into consideration being fun manner of coaching strategies. This study also proved that teaching of English grammar can effective when teaching in a very fun way by using animated videos. The finding of this study also proved that animated videos applicable to language teaching. This animated based strategy of teaching is building the better understanding to enhance the learning towards the English grammar as well retain 
the grammar rules and regulations which make the students board. This takes a look at investigated the consequences of teaching with animated based totally movies on the 9 students of the fourth graders on the Grate Arab Revolt Primary School. This takes a look at turned into comparing gaining knowledge of and maintaining method of acquiring simple with or without lively films. This experiment went out into two parts. In first part college students taught with traditional manner by way of the use of the chalk and board. In $2 \mathrm{~d}$ part same students taught with the usage of lively films. These animated movies provide the visual and emotional stage of learning lead the EFL students to a better understanding of how language works. The statistically analysis confirmed the fine outcomes in the favor of animation based getting to know that changed into conducted in the shape of animated films.

Pinter et al, (2012) intends to degree the effect of interacted animations at the pupil's performance. Two guides were covered; one becomes analog and digital electronics and 2nd turned into microcontrollers. This examine carried out in three years. Manipulate institution turned into dealt with traditional method and experimental group turned into handled with interacted flash animations constructed from the chosen components of direction. This study claimed that use of informational technologies becomes the study easier, faster and more efficient for transfer the knowledge in education process. The outcomes showed that studying with nicely created interactive animations may want to have tremendous effects on maximum students' instructional overall performance.

The aim and scope of this study will highlights the importance and significance of the usage of animation in English learning concepts. The scope of this study to set forth a platform to the teacher to utilize animation in English teaching learning process. Improving teaching methods of English is urgently needed as it is the language of modern technology, science, art, politics, medicine, and other subjects. Since teachers always strive hard to capture the learners' attention, concerted efforts are needed to charter a well-planned program for this purpose. In fact, collaboration to improve such effective methods and programs will be vital to the efficient teaching.

\section{Hypotheses}

$\mathbf{H}_{\mathrm{O}} \mathbf{1}$ There is no significant difference between the mean scores of control group taught through animation based learning and experimental group taught through traditional method of teaching on the post-test.

Ho2 There is no significant difference between the mean scores of high, mediocre and low achievers of traditional method of teaching as compared to high, mediocre and low achievers of animation-based leaning on post-test.

\section{Research Design}


The study was experimental in nature that's why Experimental design was used to conduct this study. The Pretest-Posttest Equivalent-Groups Design was selected from the rue Experimental Design.

\section{Material and Methodology}

The aim of the study was to compare the animation based learning and traditional method of teaching in English subject. For this purpose, Dar e Arqam School Model Town Campus Faisalabad City was selected as the population of this study. All fourth graders (44) were selected from Dar-e-Arqam School Model Town Campus Faisalabad City which studied in two sections. One section of (22) students considered as an experimental group and other section of (22) students presented the control group. Experimental group (E) was treated with the animation-based learning and Control group (C) treated with the traditional method of teaching. In order to examine the student's academic achievements in English subject through two methodology animation based learning and traditional method of teaching, constructed student's achievements test (SAT). The test was designed accordingly to the content which was selected for this study. Two test Pre-Test and Post-Test prepared for this study. Test included deferent types of questions which were basically based on the conceptual learning about the English grammar. Both test pretest and post-test carried equal marks. Pre-test and Post-test prepared according to the level of Bloom's Taxonomy. Four levels (Remembering, Understanding, Apply and Analyze) were focused.

Researcher carried out the research by herself. She taught both control and experimental groups. She taught control group with traditional method and experimental group with animation method. She followed the prepared lesson planning for both groups.

Firstly, pre-test has been taken from both groups. This pre-test prepared from the workbook of grade three which was implemented in the selected school. The purpose of this test was to examine the previous knowledge of both groups. Results of each test were statistically analyzed.

The process of teaching timing was 45 minutes. Firstly, teacher motivated the students for learning than teacher started teaching. After delivered new knowledge, teacher started guided practice. After this session, students did independent practice. At the end, teacher was given home assignment task to the students.

After treatment, post-test has been taken from both control and experimental group. Result of both tests was statistically analyzed.

Pre-test and post-test results of both control and experimental group compared and statistically analyzed. 
Table 1

Distribution of the Sample

\begin{tabular}{ccc}
\hline Experimental & Control & Total \\
\hline 22 & 22 & 44 \\
\hline
\end{tabular}

Table 2

Table of Specification (Pre-Test)

\begin{tabular}{cccccc}
\hline Questions & Remember & Understand & Apply & Analyze & Marks \\
\hline 1 & - & - & 4 items & - & 4 Marks \\
\hline 2 & - & 3 items & - & - & 3 Marks \\
\hline 3 & - & 5 items & - & - & 5 Marks \\
\hline 4 & 2 items & - & - & - & 5 Marks \\
\hline 5 & - & 5 items & - & - & 5 Marks \\
\hline 6 & - & 6 items & - & - & 3 Marks \\
\hline 7 & - & - & - & 5 items & 5 Marks \\
\hline Total & 2 items & 19 items & 4 items & 5 items & 30 Marks \\
\hline Percentage & $6.6 \%$ & $63.3 \%$ & $13.3 \%$ & $16.6 \%$ & \\
\hline
\end{tabular}

Table 3

Table of Specifications (Post-Test)

\begin{tabular}{cccccc}
\hline Questions & Remember & Understand & Apply & Analyze & Marks \\
\hline 1 & - & - & 3 items & - & 6 Marks \\
\hline 2 & - & 1 item & - & - & 2 Marks \\
\hline 3 & - & 3 items & - & - & 3 Marks \\
\hline 4 & 2 items & - & - & - & 5 Marks \\
\hline 5 & - & 10 items & - & - & 5 Marks \\
\hline 6 & 4 items & 5 items & - & - & 5 Marks \\
\hline 7 & - & - & - & 8 items & 4 Marks \\
\hline Total & 6 items & 19 items & 3 items & 8 items & 30 Marks \\
\hline Percentage & $20 \%$ & $63.3 \%$ & $10 \%$ & $26.6 \%$ & \\
\hline & & & & &
\end{tabular}

Results and Discussions

Table 4

Mean Scores of Control Group and Experimental Groups on Pre-Test

\begin{tabular}{cccccccc}
\hline Groups & $\mathbf{N}$ & $\begin{array}{c}\text { Mean } \\
\text { Scores }\end{array}$ & Std. D & DF & T. Value & $\begin{array}{c}\text { Sig. Value } \\
\text { (2-tailed) }\end{array}$ & Sig. Level \\
\hline Control Group & 22 & 17.11 & 16.330 & 32 & -1.400 & .169 & $.258^{*}$ \\
\hline $\begin{array}{c}\text { Experimental } \\
\text { Group }\end{array}$ & 22 & 19.55 & 5.127 & 40.262 & -1.400 & .169 & \\
\hline
\end{tabular}

*Not Significant

Table (4) shows that the mean scores of both experimental group and control group were not found statistically significant at 0.05 in the pre-test. The calculated 
value $\left(.258^{*}\right)$ was greater than the table value $(0.05)$. Hence both groups were equal at the beginning of the treatment.

Table 5

Mean Scores of Control Group and Experimental Groups on Post-Test

\begin{tabular}{cccccccc}
\hline Groups & $\mathbf{N}$ & $\begin{array}{c}\text { Mean } \\
\text { Scores }\end{array}$ & Std. D & DF & T. Value & $\begin{array}{c}\text { Sig. Value } \\
\text { (2-tailed) }\end{array}$ & $\begin{array}{c}\text { Sig. } \\
\text { Level }\end{array}$ \\
\hline Control Group & 22 & 22.23 & 4.641 & 42 & -6.929 & .000 & $.000^{*}$ \\
\hline $\begin{array}{c}\text { Experimental } \\
\text { Group }\end{array}$ & 22 & 29.30 & 1.161 & 23.628 & -6.929 & .000 & \\
\hline
\end{tabular}

*Significant

Table (5) shows that the mean scores of both experimental group and control group after treatments in the subject of English were found statistically significant at 0.05 in the post-test. The calculated value $\left(.000^{*}\right)$ was smaller than the table value (0.05). Hence both groups were significant. It shows that teaching through animation methodology has great impact on the student's achievements than teaching through traditional methodology.

Table 6

Mean Scores of High, Mediocre and Low Achievers of the Control Group on PostTest

\begin{tabular}{cccccc}
\hline Groups & N & Mean Scores & Std. D & F. Value & Sig. Level \\
\hline High Achievers & 8 & 27.00 & 2.000 & 37.552 & $.000^{*}$ \\
\hline Mediocre & 6 & 22.17 & 1.472 & & \\
\hline Low Achievers & 8 & 17.50 & 2.739 & & \\
\hline Total & 22 & 22.23 & 4.641 & & \\
\hline
\end{tabular}

*Significant

Table (6) shows that mean scores of high, mediocre and low achievers of the control group was found statistically significant in the post-test. The calculated value $\left(.000^{*}\right)$ was smaller than the table value $(0.05)$. Hence three groups were significant. It shows that high, mediocre and low achievers of control group were not equal after treatment. It appears that all students have different mental level. They were showed different performance according to their mental ability through traditional method of teaching in English subject.

Table 7

Mean Scores of High, Mediocre and Low Achievers of the Experimental Group on Post-Test

\begin{tabular}{cccccc}
\hline Groups & N & Mean Scores & Std. D & F. Value & Sig. Level \\
\hline High Achievers & 8 & 30.00 & .000 & 19.694 & $.000^{*}$ \\
\hline Mediocre & 6 & 30.00 & .000 & & \\
\hline Low Achievers & 8 & 28.06 & 1.148 & & \\
\hline Total & 22 & 29.30 & 1.161 & & \\
\hline
\end{tabular}

*Significant 
Table (7) shows that mean scores of high, mediocre and low achievers of the experimental group was found statistically significant in the post-test. The calculated value $\left(.000^{*}\right)$ was smaller than the table value $(0.05)$. Hence three groups were significant. It shows that high, mediocre and low achievers of experimental group were not equal after treatment. It appears that all students have different mental level. They were showed different performance according to their mental ability through animation-based learning in English subject.

\section{Findings}

1. The study was based on comparison of two teaching methodologies. On the purpose of comparison, control group and experimental group were compared through the results of pre-test. The results showed that the mean scores both groups control group and experimental group were not statistically significant in the subject of English as calculated P-value $\left(.258^{*}\right)$ at the table value $\left(0.05^{*}\right)$. Hence, both groups were statistically equal in the beginning of the study. In other hand, the results of control group and experimental group were statistically significant in post-test. The calculated p-value $\left(.000^{*}\right)$ smaller than the table value $\left(0.05^{*}\right)$. So, the animation way of teaching highly effected than the traditional way of teaching.

2. In more description, there was statistically significant difference between the performance of high, mediocre and low achievers of control group on post-test. Similarly, there was statistically significant difference between the performance of high, mediocre and low achievers of experimental group in post-test. But the mean scores of high, mediocre and low achievers of experimental group was much better as

Compared to the mean scores of high, mediocre and low achievers of control group which later went in the favor of animation-based learning.

Ho1 Experimental group showed the best performance through animation-based learning than the performance of control group through traditional method of teaching on the post-test. The mean scores of both control and experimental group were statistically significant at 0.05 on the post- test. Hence, the null hypothesis that, "There is no significant difference between the mean scores of control group taught through animation based learning and experimental group taught through traditional method of teaching on the post-test" was rejected. The p-value $\left(.000^{*}\right)$ was smaller than the table value (0.05). It means that animation-based learning was best methodology than the traditional method of teaching.

Ho2 The performance of high achievers of experimental group was statistically significant than the performance of high achievers of control group on the post-test. Similarly, the performance of mediocre achievers of experimental 
group was better than the performance of mediocre achievers of control group on the post-test. Furthermore, the performance of low achievers of experimental group was also significant than the performance of control group on the post-test. Thus, the null hypothesis that, "There is no significant difference between the mean scores of high, mediocre and low achievers of traditional method of teaching and high, mediocre and low achievers of animation-based leaning on post-test" was rejected at 0.05 . It's mean that animation-based learning methodology was better than the traditional method of teaching.

\section{Conclusions}

1. Finding of the study shows that statistically significant difference was found between two teaching methodologies animation based learning and traditional method of teaching in English subject. So, animation-based learning best teaching way than the traditional method of teaching.

2. The effectiveness of high, mediocre and low achievers of experimental group was higher than the high, mediocre and low achievers of control group. It showed that animation-based learning great impact on every student than the traditional method of teaching.

\section{Recommendations}

In the light of analysis of data findings and conclusions, following recommendations are suggested.

1. English teachers are suggested that to use animation based learning for the improvement of Basic English Grammar Concepts. Hopefully, English teacher can develop their creativity in teaching English grammar with the help of animation based learning like animation based videos, animation based pictures and animation based short stories.

2. All stockholders of curriculum wing should be design and prepare the animation based material for private as well as public sectors.

3. All institutions should be played a vital role to provide the strong opportunities to utilize the animation techniques as teaching tools.

4. Educational libraries should be entertained and facilitated the researchers, students, teachers as well as visitors with animated sources.

5. Animation software should be introduced in more effective way in all educational fields and they workout in all subjects as well as should be prepared learning material regarding the difficult concepts through more effective and understandable way at all levels. 


\section{References}

Abdo, I. B., \& Al-Awabdeh, A. (2017). Animated Videos Prove to be Beneficial in Teaching English Grammar as EFL: A Neurological Study of How Students Learn and Retain English Grammar. Creative Education, 08(09), 1415-1423. doi:10.4236/ce.2017.89099

Ahmad, M. (2016). Ilmi Principles of education. Lahore: Ilmi Kitab Khana, Lahore, Pakistan.

Dwyer, F. \& Dwyer, C. (2003). Effect of Animation in Facilitating Knowledge Acquisition. Paper Presented at the Meeting of Pennsylvania Educational Research Association, Hershey, PA.

Islam, B., Ahmed, A., Islam, K., \& Shamsuddin, A. K. (2014). Child Education Through Animation: An Experimental Study. International Journal of Computer Graphics $\mathcal{E}$ Animation,4(4), 43-52. doi:10.5121/ijcga.2014.4404

Liu, Chunyang, \& Fei Long, (2014). 'The Discussion of Traditional Teaching and Multimedia Teaching Approach in College English Teaching'. Pp. 31-33 in. Atlantis Press.

Pinter, Robert, DragicaRadosav, \& Sanja MaravićČisar, (2012). 'Analyzing the Impact of Using Interactive Animations in Teaching'. International Journal Of Computers Communications \& Control 7(1):147-62. doi: 10.15837/ijccc.2012.1.1430.

Rosen, Yigal. (2009). 'The Effects of an Animation-Based On-Line Learning Environment on Transfer of Knowledge and on Motivation for Science and Technology Learning'. Journal of Educational Computing Research 40:451-67. doi: 10.2190/EC.40.4.d.

Sequeira, A. H. (2012). 'Introduction to Concepts of Teaching and Learning'. SSRN Electronic Journal. doi: 10.2139/ssrn.2150166. 